\title{
Spatial and temporal variation of the nutrients in the sediment and leaves of two Brazilian mangrove species and their role in the retention of environmental heavy metals
}

\author{
Elaine Bernini ${ }^{1 *}$, Maria A. B. da Silva ${ }^{1}$, Tania M. S. do Carmo $^{2}$ and Geraldo R. F. Cuzzuol ${ }^{3}$ \\ ${ }^{1}$ Laboratory of Environmental Sciences, State University of the North Fluminense. Av. Alberto Lamego, 2000, \\ Horto, 28015-602, Campos dos Goytacazes, Rio de Janeiro, Brazil. \\ ${ }^{2}$ Universidade Federal do Espírito Santo, Center for Human and Natural Sciences, Mangrove Bioecology Laboratory. \\ ${ }^{3}$ Universidade Federal do Espírito Santo, Center for Human and Natural Sciences, Biology Department. \\ *Corresponding author: elainebernini@hotmail.com \\ Received: 26 June 2010; Accepted: 25 October 2010
}

\begin{abstract}
Spatial and temporal variation of the nutrient concentrations in leaves and sediment between the roots of Laguncularia racemosa (L.) Gaertn. $f$ and Rhizophora mangle L. was analyzed in the mangrove forest of the estuary of São Mateus River, Espírito Santo, Brazil. In leaves, the nutrients followed the sequence: $\mathrm{N}>\mathrm{Ca}>\mathrm{K}>\mathrm{Mg}>\mathrm{S}>\mathrm{P}>\mathrm{Fe}>\mathrm{Mn}>\mathrm{Zn}>\mathrm{Cu}$, and there were significant differences between species and sites studied. In general, the levels of $K$ were higher in the dry season compared to the rainy season for both species analyzed while $\mathrm{Ca}$ and $\mathrm{Cu}$ showed higher concentrations in the rainy season for Laguncularia racemosa. In the sediment, the nutrients followed the sequence: $\mathrm{Mg}>\mathrm{Ca}>\mathrm{Fe}>\mathrm{K}>\mathrm{Mn}>\mathrm{P}>\mathrm{Zn}>\mathrm{Cu}$, in general, with lower concentrations at the site where the sediment was sandier. We observed a significant variation of nutrient concentrations in the sediment between the periods analyzed, but the seasonal pattern was not clear for all nutrients. Nutrient concentration profile found in leaves of both plant species was not correlated with concentrations found in the respective sediments. The concentration factor was less than 1.0 for Fe and between 1.0 and 3.7 for $\mathrm{Mn}, \mathrm{Zn}$ and Cu. These results provide physiological evidences about the relevance of these tree species for the role of mangroves as biogeochemical barriers to the transit of heavy metals.
\end{abstract}

Key words: Concentration factor, macronutrients, micronutrients, metals

\section{RESUMO}

A variação espacial e temporal das concentrações de nutrientes das folhas e do sedimento entre as raízes de Laguncularia racemosa (L.) Gaertn. f. e Rhizophora mangle L. foi analisada no manguezal do estuário do Rio São Mateus, Espírito Santo, Brasil. No tecido foliar, os nutrientes seguiram a ordem: $\mathrm{N}>\mathrm{Ca}>\mathrm{K}>\mathrm{Mg}>\mathrm{S}>\mathrm{P}>\mathrm{Fe}>\mathrm{Mn}>\mathrm{Zn}>\mathrm{Cu}$, havendo diferença significativa entre espécies e sítios de estudo. Em geral, os teores de $\mathrm{K}$ foram mais elevados no período seco em relação ao período chuvoso, para ambas as espécies analisadas, enquanto que Ca e Cu exibiram maiores concentrações no período chuvoso, para Laguncularia 
racemosa. No sedimento, os nutrientes seguiram a ordem: $\mathrm{Mg}>\mathrm{Ca}>\mathrm{Fe}>\mathrm{K}>\mathrm{Mn}>\mathrm{P}>\mathrm{Zn}>\mathrm{Cu}$, em geral, com menores concentrações no sítio onde o sedimento foi mais arenoso. Registrou-se variação significativa das concentrações de nutrientes do sedimento entre os períodos analisados, mas o padrão sazonal não foi claro para todos nutrientes. Concentrações de nutrientes determinadas nas folhas de ambas as espécies não se correlacionaram com as concentrações dos respectivos sedimentos. 0 fator de concentração foi menor que 1,0 para Fe e entre 1,0 e 3,7 para Mn, Zn e Cu. Estes resultados fornecem evidências fisiológicas sobre a relevância destas espécies arbóreas para o papel dos manguezais como barreira biogeoquímica ao trânsito de metais pesados.

Palavras chave: fator de concentração, macronutrientes, micronutrientes, metais

\section{INTRODUCTION}

Mangroves are a coastal ecosystem subject to a tidal regime and are found in tropical and subtropical regions, mainly in sheltered areas such as estuaries, bays and lagoons (Tomlinson, 1986). Mangroves are among the most productive ecosystems in the world (Kathiresan and Bingham, 2001; Alongi, 2009) and approximately $50 \%$ of the primary productivity of this ecosystem is exported to the oceans in the form of organic matter (Robertson et al., 1992; Dittmar and Lara, 2001; Jennerjahn and Ittekkot, 2002). The exportation of organic matter and dissolved nutrients from mangroves is important for the productivity of coastal waters because it has a known effect in food chains (Lugo and Snedaker, 1974; Alongi, 1990; Jennerjahn and Ittekkot, 2002; Dittmar et al., 2006).

The role of mangroves in the retention of anthropogenic contaminants is widely known (Aragon et al., 1986; Silva et al., 1990; Lacerda, 1997; Machado et al., 2002). Studies conducted in field and laboratory indicate that the mangroves act as efficient biogeochemical barriers in regards to the transit of heavy metals in coastal areas at both abiotic (by immobilization of metals in sediment in unbioavailable forms) and biotic level (metal retention in perennial tissues) (Harbison, 1986; Lacerda et al., 1991; Tam and Wong, 1996; Machado et al., 2002). Thus, low export of metals in organic matter from mangrove forests occurs, and consequently, low contamination of food chains based on the detritus from mangrove (Lacerda et al., 1988; Silva et al., 1998).

The nutrients in the sediment of mangroves vary spatially and temporally, depending on various factors such as flooding frequency, availability of fresh water, redox potential, granulometry and $\mathrm{pH}$, which can affect the form and availability of chemical elements (Lacerda et al., 1985; Ball, 1988). However, plants exhibit selective absorption of nutrients, as shown by the fact that the concentrations of elements in the leaves do not correlate with the contents of the elements in the sediment (Lacerda et al., 1986; Medina et al., 2001).

This study describes the results of a systematic sampling in the sediments and leaves of two tree species in the mangrove of the estuary of the São Mateus River, ES. The objective was to evaluate the spatial and temporal variation of nutrient concentrations in these compartments and estimate the relevance of these species for the role of mangroves in the retention of environmental heavy metals.

\section{MATERIAL AND METHODS}

The mangrove estuary of the São Mateus River is located southeast of the Municipality of Conceição da Barra (Figure 1), in the State of Espirito Santo, Brazil (18 $35^{\prime} \mathrm{S}$ and $39^{\circ} 44^{\prime} \mathrm{W}$ ). The climate of this region is tropical humid. In the 1990's, the average lowest temperatures were observed in the months from June to August and the highest temperatures from January to March (Figure 2). The lowest rainfall was recorded from May to September and the highest from October to April (data source: Capixaba Research Institute, Technical Assistance and Rural Extension, Incaper Linhares, ES, $19^{\circ} 24^{\prime} \mathrm{S}$ and $40^{\circ} 04^{\prime} \mathrm{W}$, located approximately $90 \mathrm{~km}$ from the study area). The estuary is under a micromareal regime with semidiurnal tides. Based on data from the Terminal de Barra do Riacho, ES (19² $24^{\prime}$ S and $40^{\circ} 03^{\prime}$ ' W), between 1998 and 2000, the mean tide was $0.8 \mathrm{~m}$ (Directorate of Hydrography and Navigation, Navy Department). 


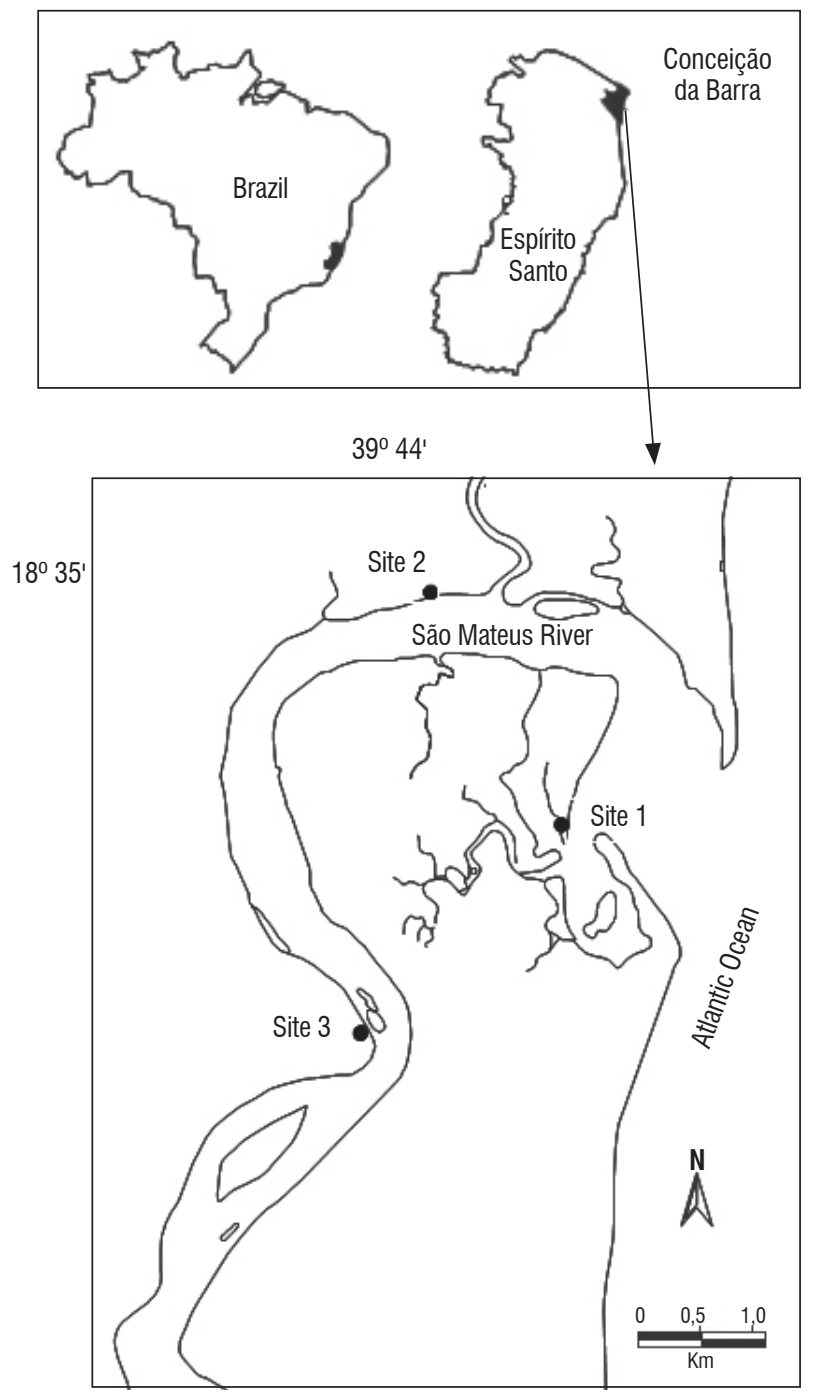

Figure 1. The location of sites in the mangrove of the estuary of the São Mateus River, Espirito Santo, Brazil, used in this study. Modified from Bernini et al. (2006).

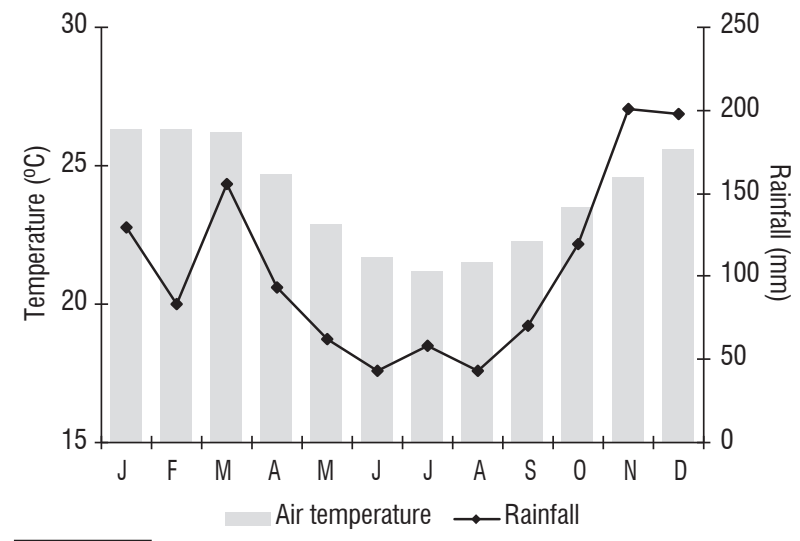

Figure 2. Monthly average temperatures and total average rainfall for the period of January 1990 to December 1999 for the northern region of Espírito Santo (Data source: Capixaba Research Institute. Technical Assistance and Rural Extension. Incaper).

The mangrove estuary of the São Mateus River occupies an area of approximately $11 \mathrm{~km}^{2}$ (Vale, 1999) and it consists of Avicennia germinans (L.) Stearn., Avicennia schaueriana Stapf and Leechm ex Moldenke., Laguncularia racemosa (L.) Gaertn. f. e Rhizophora mangle L. (Silva et al., 2005). This mangrove has frequently been affected by different types of degradation such as sedimentation, deposition of waste, domestic sewage discharge, cutting of trees to obtain firewood and as a landfill for irregular housing.

The study was conducted at the three study sites where Silva et al., (2005) analyzed the structure of the mangrove forest (Table 1) in the estuary of the São Mateus River (Figure 1). Sites 1 and 2 were located in the lower estuary, under greater tidal influence and site 3 was located in the middle estuary. Considering the physiographic types of mangrove forests classified by Lugo and Snedaker (1974) and later modified by Cintrón et al., (1985), the study area at site 1 is a fringe and the other sites are riverine.

Table 1. Structural parameters of the vegetation in three different sites in the mangrove of the estuary of the São Mateus River (Silva et al., 2005). DBH $=$ diameter at breast height. * the data are mean \pm SE.

\begin{tabular}{cccccc}
\hline Site & Height $(\mathbf{m})^{*}$ & $\begin{array}{c}\text { DBH average } \\
(\mathbf{c m})\end{array}$ & $\begin{array}{c}\text { Basal Area } \\
\left(\mathbf{m}^{2} \mathbf{h a}^{-1}\right)\end{array}$ & $\begin{array}{c}\text { Density } \\
\left(\text { individual ha-1 }^{-1}\right)\end{array}$ & Dominant species \\
\hline S1 & $5.6 \pm 1.5$ & 8.1 & 7.5 & 1,450 & Rhizophora mangle \\
S2 & $5.4 \pm 1.8$ & 8.2 & 7.2 & 1,225 & Rhizophora mangle \\
S3 & $7.9 \pm 1.8$ & 14.0 & 17.9 & 1,100 & Laguncularia racemosa \\
\hline
\end{tabular}

At each site we selected five Laguncularia racemosa trees (> $1 \mathrm{~m}$ tall) and five Rhizophora mangle trees (> $1 \mathrm{~m}$ tall) on the border of the mangrove (5 $\mathrm{m}$ away from the river).
These species were chosen because they are present in the three study sites. From each tree we collected 40 adult green leaves, from the third or fourth node on branches exposed 
to the sun. The first collection was in November 1998 (rainy season) and the second in May 1999 (dry season). The results for the second collection are from the data collected by Bernini et al., (2006). The samples were packed in previously labeled and plastic bags sent to the Incaper Laboratory of Chemical and Physical Analysis for analysis.

The nutrient content of the leaves was determined using methods described in Sarruge and Haag (1974) and Silva (1981). Briefly, total nitrogen was determined by Microkjeldahl digestion and for extraction of $\mathrm{Ca}, \mathrm{Cu}, \mathrm{Fe}, \mathrm{K}, \mathrm{Mg}, \mathrm{Mn}, \mathrm{P}, \mathrm{S}$ and $Z n$ we used nitric-perchloric acid digestion. The determination of total phosphorus was done by colorimetry $(725 \mathrm{~nm})$ and the other elements by conventional atomic absorption spectrophotometry. After digestion, sulfur was determined by gravimetric determination, based on the precipitation of sulfur by barium chloride, in the form of barium sulphate.

At each site we performed in situ, $3 \mathrm{pH}$ measurements (potentiometer model pHTestr 2TM) and salinity (refractometer model 10049 American Optical, accurate to \pm 1 ) of the interstitial water (30 $\mathrm{cm}$ deep) between the roots of trees. Additionally, we collected 5 sediment samples $(15 \mathrm{~cm})$ at each site. The granulometry of the sediment was determined by densimetry. The textural classification followed the Shepard methodology, according to Suguio (1973), based on the percentage of sand, silt and clay. The organic matter (fraction $<2 \mathrm{~mm}$ ) was determined by an indirect method (wet digestion with potassium dichromate and sulfuric acid).

Chemical elements in the sediment were determined for the $<2 \mathrm{~mm}$ fraction, according to the methodology described in Embrapa (1997). Briefly, the extraction of mobile fractions of $\mathrm{P}, \mathrm{K}, \mathrm{Fe}, \mathrm{Mn}, \mathrm{Zn}$ and Cu was carried out with a solution of $0.05 \mathrm{~N} \mathrm{HCl}+0.025 \mathrm{~N} \mathrm{H}_{2} \mathrm{SO}_{4}$, in a 1:5 soil: extractant solution. The determination of $\mathrm{K}$ was made by flame photometry, of $\mathrm{P}$ by colorimetry $(725 \mathrm{~nm})$ and the other elements by conventional atomic absorption spectrophotometry. $\mathrm{Ca}$ and $\mathrm{Mg}$ were extracted with $1 \mathrm{~N} \mathrm{KCl}$ and determined by the complexometric method with the use of EDTA (titration). Due to logistical problems, it was not possible to determine the $\mathrm{Na}$ concentrations in leaves and sediment.

Data were analyzed with a 3-way ANOVA, considering as independent factors: the study site, the period (rainy or dry) and species. The least significant difference was determined by the Tukey Test. When the assumptions for the application of the F Test were not met, a logarithmic transformation of the data was done (Zar, 1996). The Pearson correlation coefficient was calculated for the nutrients analyzed in leaves and sediment and we applied the Student Test to test the significance of the correlations. The leaf concentration was divided in the concentration of the sediment to determine the concentration factor (CF), according to Salisbury and Ross (1992). Statistical analysis was performed using Statistic 6.0.

\section{RESULTS}

The concentration of macro and micronutrients in the leaves of Laguncularia racemosa and Rhizophora mangle followed the sequence: $\mathrm{N}>\mathrm{Ca}>\mathrm{K}>\mathrm{Mg}>\mathrm{S}>\mathrm{P}>\mathrm{Fe}>\mathrm{Mn}>$ $\mathrm{Zn}>\mathrm{Cu}$ (Figure 3). Although the sequence of abundance was similar, the nutrient concentrations varied between species. In general, Laguncularia racemosa showed higher concentrations of $\mathrm{P}, \mathrm{Fe}, \mathrm{Zn}$ and $\mathrm{Cu}$, while Rhizophora mangle showed higher contents of $\mathrm{K}, \mathrm{Mg}$ and $\mathrm{Mn}$ (Figure 3).
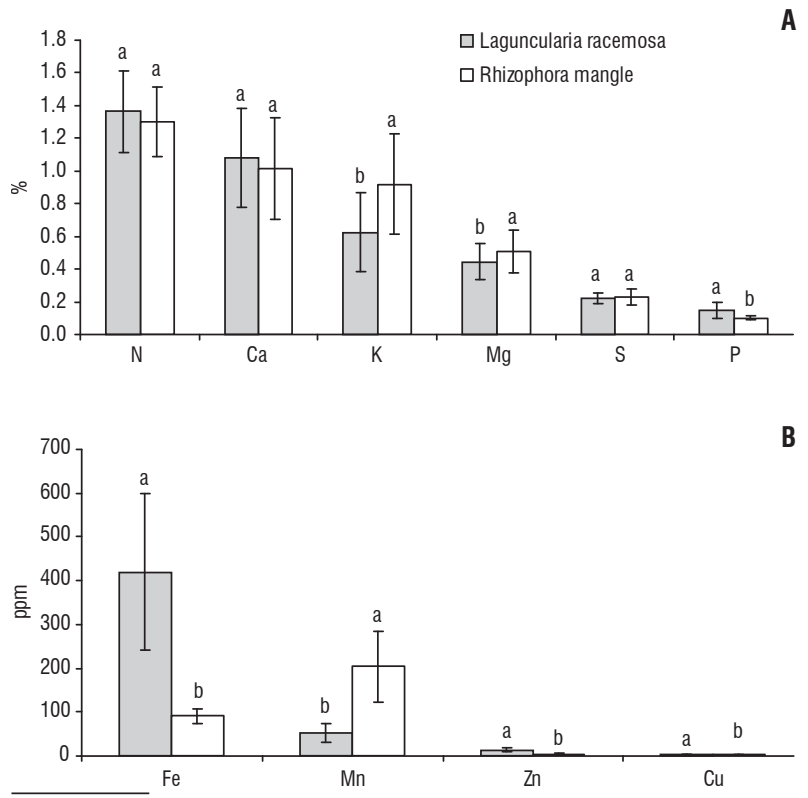

Figure 3. Mean values and standard deviation of (A) macronutrients (\%) and $(B)$ micronutrients $(\mathrm{ppm})$ in the leaves of the species studied in the mangrove of the estuary of the São Mateus River. The lowercase letters (a and b) compare nutrient concentrations between species. Values followed by different letters differ significantly $(P<0.05)$.

Regarding seasonal variation, at site 3 for Laguncularia racemosa and sites 2 and 3, for Rhizophora mangle, the contents of $\mathrm{K}$ were higher in the dry season compared to the rainy season (Table 2). Calcium concentration in Laguncularia 
racemosa was higher in the rainy season than in the dry season at site 3 , while Cu was higher in the rainy season at site 1 (Tables 2 and 3). In general, the concentration of micronutrients in the leaf tissue was higher in the rainy season, although we did not record significant differences in relation to the dry period (Table 3).

Comparing the nutrient concentrations of the species between sites at the same time, it appears that for Laguncularia racemosa, $\mathrm{K}, \mathrm{Ca}$ and $\mathrm{Zn}$ were higher at site 1 compared to other study sites in the dry season while $\mathrm{N}$ was higher at site 2 in the rainy season (Tables 2 and 3). For Rhizophora mangle, $\mathrm{Ca}$ and $\mathrm{S}$ showed lower concentrations at site 3 compared to other study sites in the rainy season. For this species the levels of $\mathrm{Cu}$ were higher at site 3 during the rainy season (Tables 2 and 3).

For the abiotic variables in the percentage of organic matter did not show seasonal variation, but were lower at site 1 compared to the other sites sediment (Table 4). At this site, the sediment presented coarser characteristics, being classified as sandy. The salinity of interstitial water was lower at site 3 . At this site, the salinity was higher in the dry season compared to the rainy season. This trend was also observed at the other study sites, although there were no show significant statistical differences. The $\mathrm{pH}$ of the interstitial water did not show significant differences between periods and study sites (Table 4).

The nutrients in the sediment varied between periods and study sites (Figure 4). The general sequence of abundance was: $\mathrm{Mg}>\mathrm{Ca}>\mathrm{Fe}>\mathrm{K}>\mathrm{Mn}>\mathrm{P}>\mathrm{Zn}>\mathrm{Cu}$. Concentration of $P$ was higher in the rainy season compared to the dry period at all study sites. The nutrients $\mathrm{K}, \mathrm{Ca}$, Fe and $\mathrm{Mn}$ presented higher values during the rainy season at site 1 . At site 3 , the $\mathrm{Mg}$ was higher during the rainy season. $\mathrm{Zn}$ had lower concentrations during the rainy season at site 1 , while $\mathrm{Cu}$ had this behavior during the dry season (Figure 4).

Table 2. Mean and standard deviation of concentration of macronutrients (\%) in the leaves of Laguncularia racemosa and Rhizophora mangle in the mangrove in the estuary of the São Mateus River. Espirito Santo. Capital letters ( $A$ and B) compare the concentrations between sites in the same period (rainy $x$ rainy or dry $x$ dry) for each species and lowercase letters ( $a$ and $b$ ) compare the concentrations between the periods within each site (rainy $x$ dry). Values followed by different letters present significant differences $(P<0.05)$.

\begin{tabular}{|c|c|c|c|c|c|c|c|}
\hline & & $\mathbf{N}$ & $\mathbf{P}$ & K & $\mathrm{Ca}$ & $\mathrm{Mg}$ & $S$ \\
\hline \multirow{9}{*}{ 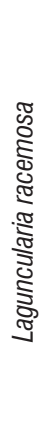 } & Site 1 & & & & & & \\
\hline & Rainy & $1.02 \pm 0.11 \mathrm{Ba}$ & $0.12 \pm 0.02 \mathrm{Aa}$ & $0.45 \pm 0.10 \mathrm{Aa}$ & $1.12 \pm 0.13 \mathrm{Aa}$ & $0.43 \pm 0.09 \mathrm{Aa}$ & $0.24 \pm 0.03 \mathrm{Aa}$ \\
\hline & Dry & $1.27 \pm 0.35 \mathrm{Aa}$ & $0.12 \pm 0.02 \mathrm{Aa}$ & $1.53 \pm 0.20 \mathrm{Aa}$ & $1.09 \pm 0.30 \mathrm{Aa}$ & $0.56 \pm 0.14 \mathrm{Aa}$ & $0.24 \pm 0.03 \mathrm{Aa}$ \\
\hline & Site 2 & & & & & & \\
\hline & Rainy & $1.54 \pm 0.05 \mathrm{Aa}$ & $0.18 \pm 0.07 \mathrm{Aa}$ & $0.57 \pm 0.16 \mathrm{Aa}$ & $1.31 \pm 0.08 \mathrm{Aa}$ & $0.48 \pm 0.03 \mathrm{Aa}$ & $0.23 \pm 0.02 \mathrm{Aa}$ \\
\hline & Dry & $1.37 \pm 0.12 \mathrm{Aa}$ & $0.14 \pm 0.04 \mathrm{Aa}$ & $0.65 \pm 0.20 \mathrm{Ba}$ & $0.92 \pm 0.13 \mathrm{Aa}$ & $0.43 \pm 0.08 \mathrm{ABa}$ & $0.23 \pm 0.02 \mathrm{Aa}$ \\
\hline & Site 3 & & & & & & \\
\hline & Rainy & $1.37 \pm 0.09 \mathrm{ABa}$ & $0.17 \pm 0.06 \mathrm{Aa}$ & $0.53 \pm 0.13 \mathrm{Ab}$ & $1.37 \pm 0.30 \mathrm{Aa}$ & $0.48 \pm 0.04 \mathrm{Aa}$ & $0.22 \pm 0.03 \mathrm{Aa}$ \\
\hline & Dry & $1.60 \pm 0.21 \mathrm{Aa}$ & $0.15 \pm 0.02 \mathrm{Aa}$ & $1.01 \pm 0.21 \mathrm{ABa}$ & $0.67 \pm 0.16 \mathrm{Ab}$ & $0.31 \pm 0.06 \mathrm{Ba}$ & $0.17 \pm 0.03 \mathrm{Aa}$ \\
\hline \multirow{9}{*}{ 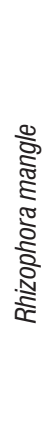 } & Site 1 & & & & & & \\
\hline & Rainy & $1.18 \pm 0.06 \mathrm{Aa}$ & $0.11 \pm 0.01 \mathrm{Aa}$ & $0.74 \pm 0.15 \mathrm{Aa}$ & $1.10 \pm 0.16 \mathrm{ABa}$ & $0.62 \pm 0.15 \mathrm{Aa}$ & $0.27 \pm 0.05 \mathrm{Aa}$ \\
\hline & Dry & $1.19 \pm 0.14 \mathrm{Aa}$ & $0.10 \pm 0.01 \mathrm{Aa}$ & $1.00 \pm 0.15 \mathrm{Aa}$ & $0.89 \pm 0.23 \mathrm{Aa}$ & $0.42 \pm 0.09 \mathrm{Aa}$ & $0.23 \pm 0.04 \mathrm{Aa}$ \\
\hline & Site 2 & & & & & & \\
\hline & Rainy & $1.50 \pm 0.37 \mathrm{Aa}$ & $0.11 \pm 0.01 \mathrm{Aa}$ & $0.67 \pm 0.15 \mathrm{Ab}$ & $1.34 \pm 0.46 \mathrm{Aa}$ & $0.58 \pm 0.11 \mathrm{Aa}$ & $0.26 \pm 0.04 \mathrm{Aa}$ \\
\hline & Dry & $1.32 \pm 0.21 \mathrm{Aa}$ & $0.09 \pm 0.01 \mathrm{Aa}$ & $1.20 \pm 0.26 \mathrm{Aa}$ & $1.04 \pm 0.22 \mathrm{Aa}$ & $0.43 \pm 0.08 \mathrm{Aa}$ & $0.23 \pm 0.02 \mathrm{Aa}$ \\
\hline & Site 3 & & & & & & \\
\hline & Rainy & $1.37 \pm 0.08 \mathrm{Aa}$ & $0.09 \pm 0.03 \mathrm{Aa}$ & $0.67 \pm 0.26 \mathrm{Ab}$ & $0.82 \pm 0.18 \mathrm{Ba}$ & $0.49 \pm 0.13 \mathrm{Aa}$ & $0.18 \pm 0.06 \mathrm{Ba}$ \\
\hline & Dry & $1.26 \pm 0.18 \mathrm{Aa}$ & $0.10 \pm 0.01 \mathrm{Aa}$ & $1.24 \pm 0.21 \mathrm{Aa}$ & $0.92 \pm 0.28 \mathrm{Aa}$ & $0.52 \pm 0.13 \mathrm{Aa}$ & $0.20 \pm 0.03 \mathrm{Aa}$ \\
\hline
\end{tabular}


Table 3. Mean and standard deviation of the concentration of micronutrients (ppm) in leaves of Laguncularia racemosa and Rhizophora mangle in the mangrove in the estuary of the São Mateus River. Espirito Santo. In the columns, capital letters ( $A$ and B) compare the concentrations between sites in the same period (rainy $x$ rainy or dry $x$ dry) for each species and lowercase letters ( $a$ and $b$ ) compare the concentrations between the periods within each site (rainy $x$ dry) . Values followed by different letters present significant difference $(P<0.05)$.

\begin{tabular}{|c|c|c|c|c|c|}
\hline & & $\mathrm{Fe}$ & Mn & $\mathrm{Zn}$ & $\mathrm{Cu}$ \\
\hline \multirow{9}{*}{ 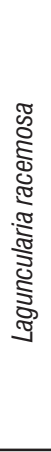 } & Site 1 & & & & \\
\hline & Rainy & $362.4 \pm 50.9 \mathrm{Aa}$ & $37.6 \pm 16.4 \mathrm{Aa}$ & $14.2 \pm 2.5 \mathrm{Aa}$ & $4.8 \pm 1.9 \mathrm{Aa}$ \\
\hline & Dry & $319.2 \pm 174.1 \mathrm{Aa}$ & $40.6 \pm 19.5 \mathrm{Aa}$ & $16.2 \pm 4.4 \mathrm{Aa}$ & $2.4 \pm 0.5 \mathrm{Ab}$ \\
\hline & Site 2 & & & & \\
\hline & Rainy & $478.0 \pm 187.0 \mathrm{Aa}$ & $69.0 \pm 10.7 \mathrm{Aa}$ & $14.2 \pm 5.4 \mathrm{Aa}$ & $3.4 \pm 0.9 \mathrm{Aa}$ \\
\hline & Dry & $300.8 \pm 73.1 \mathrm{Aa}$ & $38.0 \pm 2.8 \mathrm{Aa}$ & $9.8 \pm 2.2 \mathrm{Ba}$ & $2.0 \pm 0.7 \mathrm{Aa}$ \\
\hline & Site 3 & & & & \\
\hline & Rainy & $597.2 \pm 238.1 \mathrm{Aa}$ & $75.4 \pm 22.9 \mathrm{Aa}$ & $12.4 \pm 4.3 \mathrm{Aa}$ & $3.6 \pm 0.9 \mathrm{Aa}$ \\
\hline & Dry & $472.6 \pm 148.7 \mathrm{Aa}$ & $41.2 \pm 10.8 \mathrm{Aa}$ & $11.8 \pm 2.3 \mathrm{ABa}$ & $2.2 \pm 1.1 \mathrm{Aa}$ \\
\hline \multirow{9}{*}{ 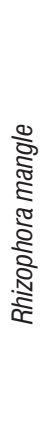 } & Site 1 & & & & \\
\hline & Rainy & $96.2 \pm 8.9 \mathrm{Aa}$ & $180.2 \pm 94.1 \mathrm{Aa}$ & $3.6 \pm 0.5 \mathrm{Aa}$ & $3.4 \pm 1.1 \mathrm{ABa}$ \\
\hline & Dry & $82.5 \pm 19.4 \mathrm{Aa}$ & $143.0 \pm 69.7 \mathrm{Aa}$ & $4.4 \pm 0.5 \mathrm{Aa}$ & $1.4 \pm 0.5 \mathrm{Aa}$ \\
\hline & Site 2 & & & & \\
\hline & Rainy & $112.0 \pm 22.7 \mathrm{Aa}$ & $200.0 \pm 86.7 \mathrm{Aa}$ & $4.8 \pm 1.3 \mathrm{Aa}$ & $1.8 \pm 0.4 \mathrm{Ba}$ \\
\hline & Dry & $85.7 \pm 11.0 \mathrm{Aa}$ & $183.0 \pm 40.8 \mathrm{Aa}$ & $4.2 \pm 0.4 \mathrm{Aa}$ & $1.0 \pm 0.0 \mathrm{Aa}$ \\
\hline & Site 3 & & & & \\
\hline & Rainy & $78.4 \pm 7.3 \mathrm{Aa}$ & $262.0 \pm 70.3 \mathrm{Aa}$ & $4.2 \pm 1.1 \mathrm{Aa}$ & $4.2 \pm 0.8 \mathrm{Aa}$ \\
\hline & Dry & $88.6 \pm 11.5 \mathrm{Aa}$ & $254.8 \pm 81.5 \mathrm{Aa}$ & $4.8 \pm 0.4 \mathrm{Aa}$ & $2.2 \pm 1.1 \mathrm{Aa}$ \\
\hline
\end{tabular}

Table 4. Mean and standard deviation of environmental variables analyzed in the study sites in the mangrove of the estuary of the São Mateus River, Espirito Santo. In the columns, capital letters ( $A$ and $B$ ) compare the values between sites in the same period (rainy $x$ rainy or dry $x$ dry) and lowercase letters (a and $b)$ compare the values between periods within each site (rainy $\mathrm{x}$ dry). Values followed by different letters present significant difference $(\mathrm{P}<0.05)$.

\begin{tabular}{|c|c|c|c|c|}
\hline & $\begin{array}{l}\text { Organic matter of } \\
\text { sediment (\%) }\end{array}$ & $\begin{array}{c}\text { Textural classification } \\
\text { of sediment }\end{array}$ & $\begin{array}{l}\text { Salinity of } \\
\text { porewater }\end{array}$ & $\begin{array}{c}\mathrm{pH} \text { of } \\
\text { porewater }\end{array}$ \\
\hline \multicolumn{5}{|l|}{ Site 1} \\
\hline Rainy & $0.60 \pm 0.28 \mathrm{Ba}$ & Sandy & $21.0 \pm 4.2 \mathrm{ABa}$ & $6.7 \pm 0.1 \mathrm{Aa}$ \\
\hline Dry & $0.86 \pm 0.62 \mathrm{Ba}$ & Sandy & $30.7 \pm 2.3 \mathrm{Aa}$ & $6.8 \pm 0.2 \mathrm{Aa}$ \\
\hline \multicolumn{5}{|l|}{ Site 2} \\
\hline Rainy & $1.70 \pm 0.85 \mathrm{Aa}$ & Sand silt mud & $23.7 \pm 3.2 \mathrm{Aa}$ & $7.0 \pm 0.3 \mathrm{Aa}$ \\
\hline Dry & $1.62 \pm 0.22 \mathrm{ABa}$ & Sand silt mud & $31.0 \pm 3.0 \mathrm{Aa}$ & $7.3 \pm 0.1 \mathrm{Aa}$ \\
\hline \multicolumn{5}{|l|}{ Site 3} \\
\hline Rainy & $1.76 \pm 0.52 \mathrm{Aa}$ & Mud sandy siltstone & $8.3 \pm 5.9 \mathrm{Bb}$ & $6.5 \pm 0.3 \mathrm{Aa}$ \\
\hline Dry & $2.02 \pm 0.19 \mathrm{Aa}$ & Mud sandy siltstone & $17.3 \pm 5.0 \mathrm{Ba}$ & $6.8 \pm 0.5 \mathrm{Aa}$ \\
\hline
\end{tabular}

As for spatial variation, we found that $\mathrm{P}, \mathrm{K}, \mathrm{Mg}$, Fe and Cu showed lower values in the sediment at site 1 compared to the other sites (Figure 4). During the dry season we recorded higher concentrations of $\mathrm{Mn}$ and $\mathrm{Zn}$ at site 3 . The latter nutrient presented the lowest content at site 1 during the rainy season, while Ca was lower in this study site during the dry season (Figure 4).
Nutrient concentrations of leaves were not correlated with concentrations in the sediment $(P>0.05)$. The concentration factors were smaller than 1.0 for $F e$ and between 1.0 and 3.7 for $\mathrm{Mn}, \mathrm{Zn}$ and $\mathrm{Cu}$ (Figure 5). The values of concentration factors for Fe and $\mathrm{Zn}$ were higher in Laguncularia racemosa and in Rhizophora mangle it exhibited higher values for $\mathrm{Mn}$ (Figure 5). 
MANGROVE SPECIES AND THEIR ROLE IN THE RETENTION OF ENVIRONMENTAL HEAVY METALS

A

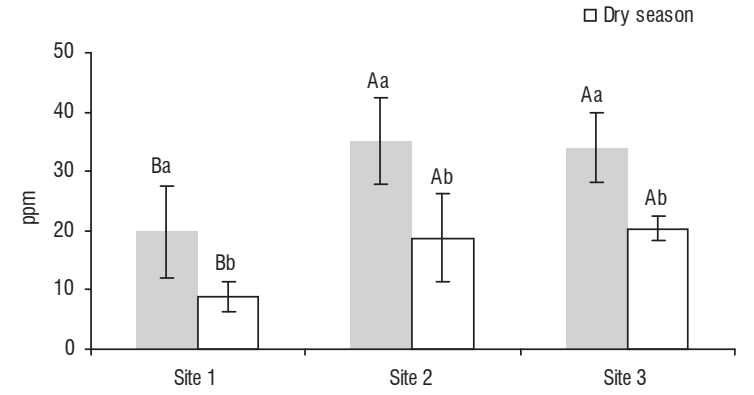

C

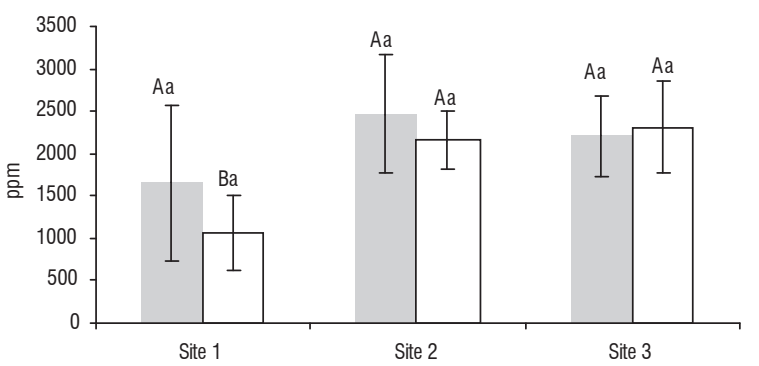

$\mathbf{E}$

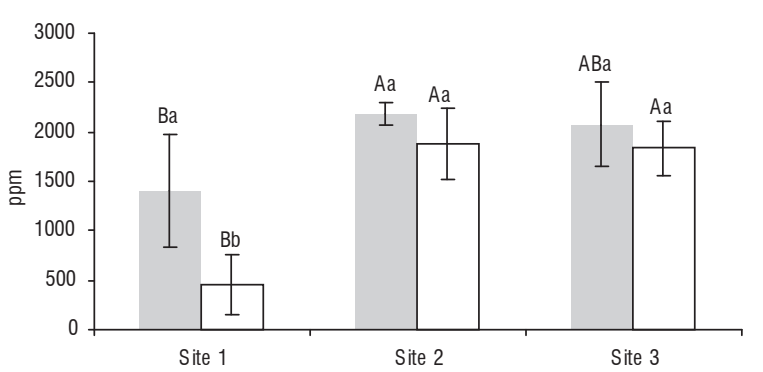

G

Manganese

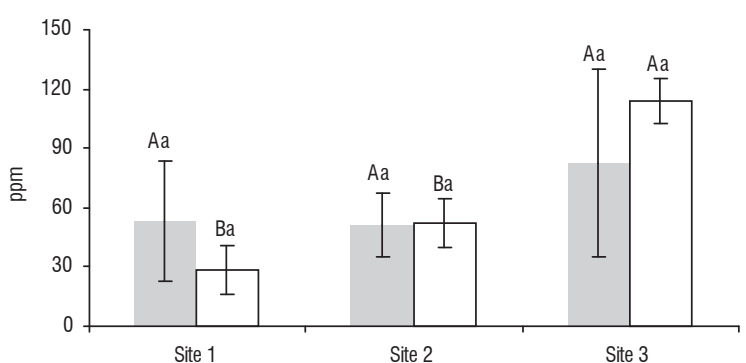

B

Potassium

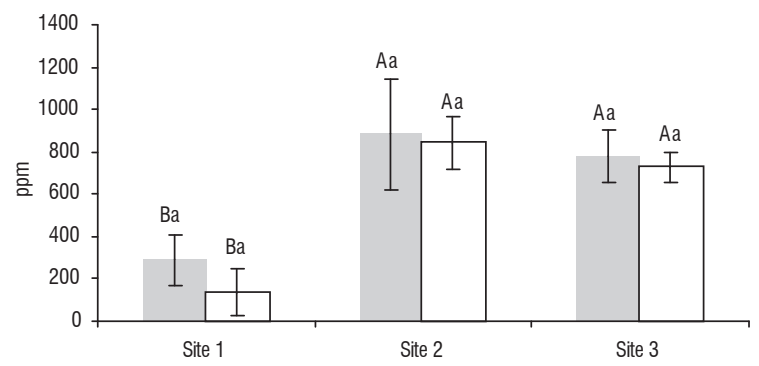

D

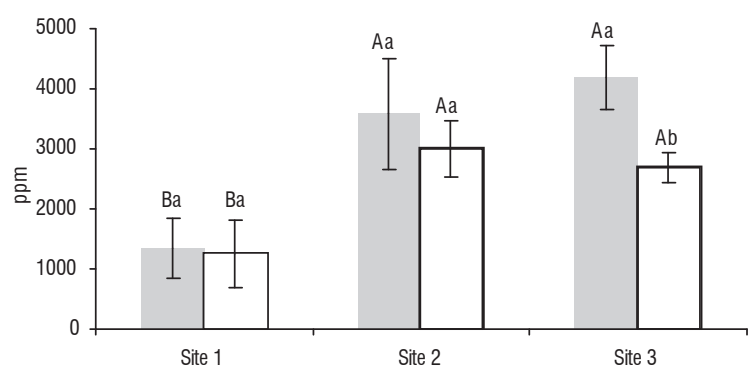

$\mathbf{F}$

Zinc

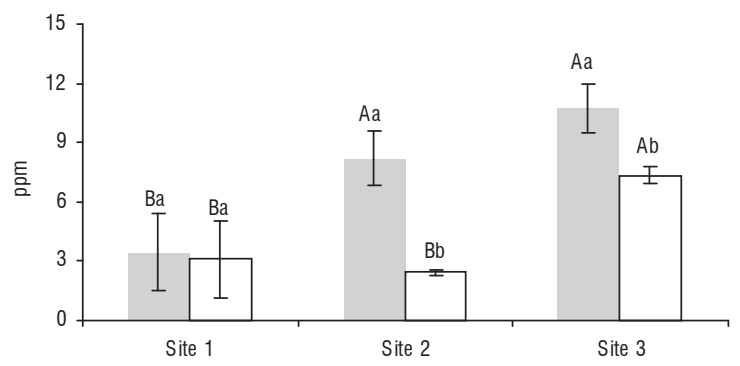

H

Copper

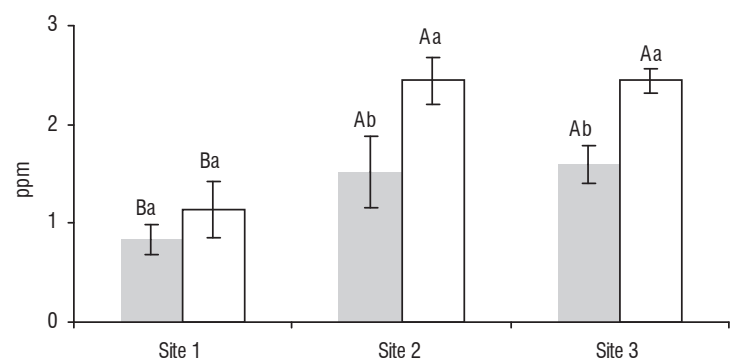

Figure 4. Concentration of nutrients in the sediment of the sites analyzed in the mangrove of the estuary of the São Mateus River. ES. The capital letters (A and B) compare the concentrations between sites in the same period (rainy $\mathrm{x}$ rainy or dry $\mathrm{x}$ dry) and the lowercase letters ( $\mathrm{a}$ and $\mathrm{b}$ ) compare the concentrations between the periods within each site (rainy $x$ dry). Values followed by distinct letters differ significantly $(P<0.05)$. 


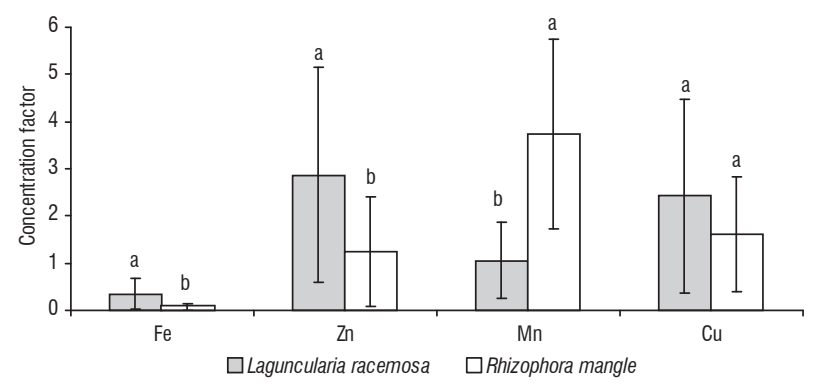

Figure 5. Mean values and standard deviation of the concentration factors of the species studied in the mangrove of the estuary of the São Mateus River. ES. The lowercase letters (a and b) compare nutrient concentrations between the species. Values followed by different letters differ significantly $(\mathrm{P}<0.05)$.

\section{DISCUSSION}

The average concentration of leaf nutrients were within the range described for other mangroves (Lacerda et al., 1986; Medina et al., 2001; Cuzzuol and Campos, 2001; Freitas et al., 2002; Medina et al., 2008; Medina et al., 2009; Bernini and Rezende, in press). Although nutrients are used by plants for essentially similar purposes, species differ in their absolute concentration and in the relative proportions of different elements, since the efficiency of nutrient uptake and preference for a particular element depends on a set of internal and external factors (Waisel, 1972; Larcher, 2000). Rhizophora mangle presented higher contents of $\mathrm{K}, \mathrm{Mg}$ and $\mathrm{Mn}$, while Laguncularia racemosa presented higher concentrations of $P$, $\mathrm{Fe}, \mathrm{Zn}$ and $\mathrm{Cu}$. This result is consistent with those observed by other authors (Lacerda et al., 1985; Cuzzuol and Campos, 2001; Bernini and Rezende, in press).

Some nutrients analyzed in leaves presented seasonal variation ( $\mathrm{K}, \mathrm{Ca}$ and $\mathrm{Cu}$ in Laguncularia racemosa and $\mathrm{K}$ for Rhizophora mangle; Tables 2 and 3). The occurrence of temporal variation in nutrient content in adult leaves of mangrove plants has been reported in literature (Clough and Attwill, 1975; Boto and Wellington, 1983; Oliveira et al., 1996; Wang et al., 2003). For other forests, such as dry tropical forests and savannas, seasonal variation of nutrients is related to mechanisms of uptake and retranslocation (Villela and Lacerda, 1992). This has also been reported for mangrove forests (Wang et al. 2003; Macfarlane et al., 2007).

Generally mangroves present low nutrient availability, especially nitrogen (Alongi et al., 1992), and retranslocation is an important mechanism for the conservation of these elements. However, retranslocation can be observed in mangroves where there is no nutrient deficiency. Although there is significant correlation between concentrations of chemical elements in sediment and mangrove leaves (Boto and Wellington, 1983) most studies show no correlation between these compartments (Lacerda et al., 1986; Medina et al. 2001; Bernini and Rezende, in press), as observed in this study. Thus, there is still no consensus on whether or not there is a seasonal pattern for the concentration of nutrients in the leaf tissue in relation to retranslocation and fertility of the sediment as commented by Wang et al., (2003).

In the mangrove of the estuary of the São Mateus River the sampling considered trees $>1 \mathrm{~m}$ tall and we collected leaves from the third or fourth node of branches exposed to the sun to standardize the sampled individuals. However, there was variation in nutrient content of the leaves of Laguncularia racemosa and Rhizophora mangle between study sites. Such behavior was expected, since the relative concentration of nutrients can vary within the same genotype, when subjected to different environmental conditions (Epstein, 1975), such as variation in the frequency of flooding, salinity and granulometry of the sediment.

In general, the spatial variation of abiotic variables was more evident than the seasonal variation. Site 3 presented lower values of salinity of interstitial water by because it had less tidal influence. The salinity of interstitial water was lower in the rainy season, reflecting the greater contribution of fresh groundwater in this period. Vale (1999) found higher values of salinity, varying between 28 and 44, in areas near the river mouth. The $\mathrm{pH}$ of interstitial water did not exhibit spatial or temporal variations, showing values similar to those reported for the mangrove of Mucuri river, Bahia (Cuzzuol and Campos, 2001), and higher when compared to the mangrove estuary of the Paraíba do Sul River, Rio de Janeiro (Bernini and Rezende, in press).

Previous studies have shown that mangrove species can develop in a variety of substrates from clay to sandy loam (Oliveira et al., 1996; Souza et al., 1996; Bernini and Rezende, 2004; Ferreira et al., 2007), as observed in this study. Site 3 is located in an environment of low energy in relation to sites 1 and 2 . This is reflected in the distribution of grain sizes. The percentage of organic matter in the sediment is low compared to other mangroves in Brazil (Carmo et al., 1995; Cuzzuol and Campos, 2001; Bernini and Rezende, 2004). 
The organic matter content of the sediment is highly variable, being influenced by the tidal regime and litter production. The low percentages can be attributed to the constant removal of litter from the sites studied, since collection of the sediment was carried out near the border of the mangrove ( $5 \mathrm{~m}$ away from the river), where tidal flooding is frequent.

The content of $\mathrm{K}$ and $\mathrm{Mg}$ in the sediment was lower than that recorded for the Baía de Sepetiba (Rio de Janeiro, Brazil), where marine influence is greater (Lacerda et al., 1985). The concentration of heavy metals ( $\mathrm{Fe}, \mathrm{Mn}, \mathrm{Zn}$ and $\mathrm{Cu}$ ) obtained in the estuary of the São Mateus River was lower when compared to other mangroves influenced by industrial activities and domestic sewage (Lacerda et al., 1993; Oliveira et al. 1998; Freitas et al., 2002; Machado et al., 2002). While land-based sources of these metals vary according to geomorphological and climatic characteristics (Lacerda et al., 1986), the low levels found here are probably due to the lack of industrial activities in the vicinity of the mangrove.

The retention and mobility of nutrients in the sediment are influenced by characteristics such as texture, organic matter content, redox potential, $\mathrm{pH}$, salinity, $\mathrm{Al}, \mathrm{Fe}$ and $\mathrm{Mn}$ content, as well as anthropogenic effluents. These parameters vary widely, so the retention and mobility of nutrients vary from one mangrove to another (Tam and Wong, 1993, 2000). Sediments with a higher percentage of sand have less capacity to retain organic matter and nutrients (Tam and Wong, 1993), as observed in this study (Table 4 and Figure 4).

The sandy texture, the lower values of organic matter and nutrients observed in the sediment of site 1 are related to rapid sedimentation that occurred in this area. The sedimentation observed at this site is due to the fact that the mouth of the São Mateus River has become unstable, with a strong process of sedimentation in the river floodplains. This has been causing erosion problems on the beach of Conceição da Barra, located on the left margin, and erosion and burial of the mangrove on the right margin of the river (Vale, 1999), that promotes tree fall of live individuals and apical death of mangrove plants in this area. High rates of sedimentation cause the mortality of mangrove trees, since this interferes with nutrient recycling and exchange of gases, due to the coverage of rhizophore's lenticels and pneumatophores (Odum and Johannes, 1975).
The marked instability of the estuary of the São Mateus River is due to variations in river flow, caused by the capture of its water for different uses (e.g. domestic and agricultural supply) and environmental disturbances (such as deforestation of the riparian forest), besides accentuation caused by natural phenomena (e.g. El Niño and La Niña). Change in river discharge alters the capacity in the sediment transport at the interface between the mainland and the sea, causing changes in the dynamics of coastal sedimentation over the years. Similarly, other studies have shown that reduction in river flow has resulted in diminishing supply of river sediments to the coast, promoting rapid geomorphological changes in the river mouths (Bonora et al.,2002; Batalla, 2003; Giri et al., 2007; Bernini et al., in press). The change in the hydrodynamics of the rivers cause coastal erosion, increased salinity intrusion, depletion of nutrients in certain areas and accelerated deposition in the sediments (Lacerda and Marins, 2002).

We registered a significant variation of nutrient concentration in the sediment between the periods analyzed, but the seasonal pattern was not clear for all nutrients. Similar results were reported by Boto and Wellington $(1983,1984)$ and Tam et al., (1995). The deposition of fine sediments may be responsible for the highest content of phosphorus and zinc during the rainy season, but does not explain the seasonal variation of the other nutrients. Nutrient concentrations in mangrove sediments are a reflection of many factors, so it is difficult to define the tendency of temporal variations of nutrient content (Tam and Wong, 1993).

There was preferential incorporation of Mn by Rhizophora mangle and $\mathrm{Fe}$ and $\mathrm{Zn}$ by Laguncularia racemosa, confirming results reported for other mangroves (Lacerda et al., 1985; Cuzzuol and Campos, 2001). The concentration factors for Laguncularia racemosa for $\mathrm{Zn}$ and $\mathrm{Cu}$ were high. The values described here are similar to those observed by Cuzzuol and Campos (2001), who described concentration factors varying from 2.2 to 2.6 for $\mathrm{Zn}$ and 1.7 to 3.2 for $\mathrm{Cu}$.

Mangroves tend to show little accumulation of heavy metals, with higher concentration of these elements in root tissue than in leaves (Silva et al., 1990; Macfarlane et al., 2007). In general, the concentration factors for heavy metals in mangrove leaves are lower than 1.0 and there was no correlation between the concentration in leaves and sediments (Lacerda et al., 1986; Thomas and Fernandez, 1997). This 
fact was observed in the mangrove of the estuary of the São Mateus River since the nutrient concentrations of leaves were not correlated with concentrations in the sediment and the values of the concentration factor for Fe was less than 1.0 for both species analyzed. This indicates that the mangrove plants inhibit the absorption of heavy metals (Lacerda, 1997).

This behavior can be attributed to the fact that there is low availability in the sediment, because heavy metals may precipitate as sulfides under anoxic conditions and become complexed with organic matter, fine sediments and $\mathrm{Fe}$ on the root surface (Harbison, 1986; Lacerda, 1997). In addition, there may be barriers in the endodermis of the root and restriction on the uptake and translocation within the plant (immobilization in the cell wall and complexation with substances such as phytochelatins; Baker and Walker, 1990).

Acknowledgements: To the Capixaba Research Institute, Technical Assistance and Rural Extension, Incaper, Linhares, for analysis of samples. To the Environmental Police of São Mateus and the Municipality of Conceição da Barra, for help concerning vessels. The authors E. Bernini and M.A.B. Silva thank PIBIC/UFES, for the granting of a Scholarship.

\section{REFERENCES}

Alongi DM (1990) Abundances of benthic microfauna in relation to outwelling of mangrove detritus in a tropical coastal region. Mar. Ecol. Prog. Ser. 63: 53-63.

Alongi, DM, Boto KG, Robertson A (1992) Nitrogen and phosphorus cycles. In: Robertson Al, Alongi DM (eds.), Tropical Mangrove Ecosystems, pp. 251-292. American Geographysical Union, Washington, DC.

Alongi DM (2009) The energetics of mangrove forests. Springer, London.

Aragon GT, Pires, VS, Lacerda LD, Patchineelam SR (1986) Distribuição espacial de nutrientes e metais pesados em sedimentos e águas superficiais em um ecossistema de manguezal. Acta Limn. Bras.1: 365-385.

Baker AJM, Walker PL (1990) Ecophysiology of metal uptake by tolerant plants. In: Shaw, A.J. (Ed.), Heavy Metal Tolerance in Plants, pp. 155-178. CRC Press, Boca Raton

Ball MC (1988) Ecophysiology of mangroves. Trees 2: 129-142.

Batalla RJ (2003) Sediment deficit in rivers caused by dams and in stream gravel mining. A review with examples from NE Spain. Cuatern. Geomorfol. 17: 79-91.

Bernini E, Ferreira R, Silva FLC, Mazurec AP, Nascimento MT, Rezende CE (in press) Alterações na cobertura vegetal do manguezal do estuário do rio Paraíba do Sul no período de 1976 a 2001. Gestão Costeira Integrada.

Bernini E, Rezende CE (2004) Estrutura da vegetação em florestas de mangue do estuário do rio Paraíba do Sul, Estado do Rio de Janeiro, Brasil. Acta Bot. Brasil. 18: 491-502.

Bernini E, Rezende CE (in press). Concentração de nutrientes em folhas e sedimentos em um manguezal do Norte do Estado do Rio de Janeiro. Gestão Costeira Integrada.
Bernini E, Silva MAB, Carmo TM, Cuzzuol GRF (2006) Composição química do sedimento e de folhas das espécies do manguezal do estuário do Rio São Mateus, Espírito Santo, Brasil. Rev. Brasil. Bot. 29: 689-699.

Bonora N, Immordino F, Schiavi C, Simeoni U, Valpreda E (2002) Interaction between catchment basin management and coastal evolution (Southern Italy). J. Coastal Res. 36: 81-88.

Boto KG, Wellington JT (1983) Phosphorus and nitrogen and nutritional status of a northern Australian mangrove forest. Mar. Ecol. Prog. Ser. 11: 63-69.

Boto KG, Wellington JT (1984) Soil characteristics and nutrient status in a Northern Australian mangrove forest. Estuaries 7: 61-69.

Carmo TMS, Brito-Abaurre MG, Senna-Melo RM, Zanotti-Xavier S, Costa MB, Horta MMM (1995) Os manguezais da Baía Norte de Vitória, Espírito Santo: um ecossistema ameaçado. Rev. Brasil. Biol. 55: 801-808.

Cintrón G, Lugo AE, Martinez R (1985) Structural and functional properties of mangrove forests. In: Arcy WGD, Correa MDA (eds.), The botany and natural history of Panama, pp. 53-66. Missouri Botanical Garden, Saint Louis, Missouri.

Clough BF, Attiwill PM (1975) Nutrient cycling in a community of Avicennia marina in a temperate region of Australia. In: Walsh GE, Snedaker SC, Teas $\mathrm{HJ}$ (eds.), Proceedings of the International Symposium on the Biology and Management of Mangroves, vol. I. Institute of Food and Agricultural Sciences pp.137-146

Cuzzuol GRF, Campos A (2001) Aspectos nutricionais na vegetação de manguezal do estuário do Rio Mucuri, Bahia, Brasil. Rev. Brasil. Bot. 24: 227234.

Dittmar T, Lara RJ (2001) Do mangroves rather than rivers provide nutrients to coastal environments south of the Amazon River? Evidence from long-term flux measurements. Mar. Ecol. Prog. Ser. 213: 67-77.

Dittmar T, Hertkorn N, Kattner G, Lara RJ (2006) Mangroves, a major source of dissolved organic carbon to the oceans. Global Biogeochem. Cy. 20: 1-7.

EMBRAPA. Centro Nacional de Pesquisa de Solos (1997) Manual de métodos de análise do solo. Embrapa, Rio de Janeiro.

Epstein E (1975) Nutrição mineral das plantas - princípios e perspectivas. EDUSP, São Paulo.

Ferreira TO, Otero XL, Vidal-Torrado P, Macías F (2007) Effects of bioturbation by root and crab activity on iron and sulfur biogeochemistry in mangrove substrate. Geoderma 142: 36-46.

Freitas H, Guedes MLS, Smith DH, Oliveira SS, Santos ES, Silva EM (2002) Characterization of the mangrove plant community and associated sedimento of Todos os Santos Bay, Bahia, Brazil. Aquat. Ecosyst. Health. 5: 217-229.

Giri C, Pengra B, Zhu Z, Singh A, Tieszen LL (2007) Monitoring mangrove forest dynamics of the Sundarbans in Bangladesh and India using multitemporal satellite data from 1973 to 2000. Estuar. Coast. Shelf Sci. 73: 91100.

Harbison P (1986) Mangrove muds - a sink and source for trace metals. Mar. Pollut. Bull. 17: 273-276.

Jennerjahn TC, Ittekkot V (2002) Relevance of mangroves for the production and deposition of organic matter along tropical continental margins. Naturwissenschaften 89: 23-30.

Kathiresan K, Bingham BL (2001) Biology of mangroves and mangrove ecosystems. Adv. Mar. Biol. 40: 81-251.

Lacerda LD (1997) Trace metals in mangrove plantas: why such low concentrations? In: Kjerfve B, Lacerda LD, Diop HS (eds.), Mangrove ecosystem studies in Latin America and Africa, pp. 171-178. Unesco, Paris.

Lacerda LD, Marins RV (2002) River damming and changes in mangrove distribution. ISME/GLOMIS Electronic Journal 2: 1-4.

Lacerda LD, Carvalho CEV, Tanizaki KF, Ovalle ARC, Rezende CE (1993) The biogeochemistry and trace metals distribution of mangrove rizospheres. Biotropica 25: 252-257. 
Lacerda LD, Martinelli LA, Rezende CE, Mozetto AA, Ovalle ARC, Victoria RL, Silva CAR, Nogueira FB (1988) The fate of trace metals in supended matter in a mangrove creek during a tidal cicle. Sci. Total Environ. 75: 249-259.

Lacerda LD, Rezende CE, Aragon GT, Ovalle AR (1991) Iron and chromium transport and accumulation in a mangrove ecosystem. Water Air Soil Poll. 57/58: 513-520.

Lacerda LD, Rezende CE, José DV, Francisco MC (1986) Metallic composition of leaves from the Southeastern Brazilian coast. Rev. Brasil. Biol. 46: 395399.

Lacerda LD, Rezende CE, José DV, Wasserman JC, Francisco MC (1985) Mineral concentration in leaves of mangrove trees. Biotropica 17: 260-262.

Larcher W (2000) Ecofisiologia vegetal. Rima, São Carlos.

Lugo AE, Snedaker SC (1974) The ecology of mangroves. Ann. Rev. Ecol. Syst. 5: 39-64.

MacFarlane GR, Koller CE, Blomberg SP (2007) Accumulation and partitioning of heavy metals in mangroves: A synthesis of field-based studies. Chemosphere 69: 1454-1464.

Machado W, Silva-Filho EV, Oliveira RR, Lacerda LD (2002) Trace metal retention in mangrove ecosystems in Guanabara Bay, SE Brazil. Mar. Poll. Bull. 44: 1277-1280.

Medina E, Cuevas E, Lugo AE (2009) Nutrient relations of dwarf Rhizophora mangle L. mangroves on peat in eastern Puerto Rico. Plant Ecol. Doi: $10.1007 / \mathrm{s} 11258-009-9650-z$

Medina E, Francisco M, Quilice A (2008) Isotopic signatures and nutrient relations of plants inhabiting brackish wetlands in the northeastern coastal plain of Venezuela. Wetlands Ecol. Manage. Doi: 10.1007/s11273-0079056-4.

Medina E, Giarizzo T, Menezes M, Carvalholira M, Carvalho EA, Peres A, Silva B, Vilhena R, Reise A, Braga FC (2001) Mangal commuties of the Salgado Paraense: ecological heterogneity alone the Bragança peninsula assessed through soil and leaf analisis. Amazoniana 16: 397-416.

Odum WE, Johannes RE (1975) The response of mangrove to man-induced environmental stress. In: Wood EJF, Johannes RE (eds), Tropical Marine Pollution, pp. 52-62. Elsevier Oceanography Series, Amsterdam.

Oliveira RR, Bressan FA, Silva Filho EV (1998) Contaminação por metais pesados no sedimento e em compartimentos bióticos de manguezais da Baía de Guanabara, RJ. Annals of the IV Simpósio de Ecossistemas Brasileiros. Aciesp, São Paulo, 1: 30-37.

Oliveira SS, Freitas HM, Accioly MC (1996) Composição química das folhas de Avicennia germinans (L.) Stearn, Laguncularia racemosa (L.) Gaertn. f. e Rhizophora mangle L. e solo do manguezal do rio Mucuri-Ba, sob ação de resíduos industriais. Sitientibus 15: 133-150.

Robertson Al, Alongi DM, Boto KG (1992) Food chains and carbon fluxes. In: Robertson Al, Alongi DM (eds), Tropical Mangrove Ecosystems, pp. 293326. American Geographysical Union, Washington, DC.
Salisbury FB, Ross CW (1992) Plant physiology. Wadsworth Publishing Company, Belmont.

Sarruge JR, Haag HP (1974) Análises químicas em plantas. Esalq, Piracicaba.

Silva DJ (1981) Análise de alimentos: métodos químicos e biológicos. Imprensa Universitária, Viçosa, 235p.

Silva CAR, Lacerda LD, Rezende CE (1990) Heavy metal reservoirs in a red mangrove forest. Biotropica 22: 339-345.

Silva CAR, Lacerda LD, Ovalle ARC, Rezende CE (1998) The dynamics of heavy metals through litterfall and decomposition in a red mangrove forest. Mang. Salt Mars. 2: 149-157.

Silva MAB, Bernini E, Carmo TMS (2005) Características estruturais de bosques de mangue do estuário do Rio São Mateus, ES, Brasil. Acta Bot. Brasil. 19: 465-471.

Souza HF, Guedes MLS, Oliveira SS, Santos ES (1996) Alguns aspectos fitossociológicos e nutricionais do manguezal da llha do Pati, Bahia, Brasil. Sitientibus 15: 151-165.

Suguio K (1973) Introdução a sedimentologia. Edgar Blucher/Edusp, São Paulo.

Tam NFY, Wong YS (1993) Retention of nutrients and heavy metals in mangrove sediments receiving wastewater of different strengths. Environ. Technol. 14: 719-729.

Tam NFY, Wong YS (2000) Spatial variation of heavy metals in surface sediments of Hong Kong mangrove swamps. Environ. Poll. 110: 195-205

Tam NFY, Li SH, Lan CY, Chen GZ, Li MS, Wong YS (1995) Nutrients and heavy metal contamination of plants and sediments in Futian mangrove forest. Hydrobiologia 295: 149-158.

Thomas G, Fernandez TV (1997) Incidence of heavy metals in the mangrove flora and sediments in Kerala, India. Hydrobiologia 352: 77-87.

Tomlinson PB (1986) The botany of mangroves. Cambridge University Press, New York. 413p.

Vale CC (1999) Contribuição ao estudo dos manguezais como indicadores biológicos das alterações geomórficas do estuário do Rio São Mateus-ES. Universidade de São Paulo, MSc thesis.

Vilela DMJ, Lacerda LD (1992) Dinâmica de nutrientes minerais em folhas de duas espécies arbóreas de Cerrado. Rev. Brasil. Biol. 52: 151-160.

Waisel Y (1972) Biology of halophytes. Academic Press, New York. 395p.

Wang WQ, Wang M, Peng L (2003) Seasonal changes in element contents in mangrove element retranslocation during leaf senescence. Plant Soil 252: 187-193.

Zar J H (1996) Biostatistical Analysis. Prentice Hall, New Jersey. 718p. 